\title{
Ovarian Granulosa Cell Tumor
}

National Cancer Institute

\section{Source}

National Cancer Institute. Ovarian Granulosa Cell Tumor. NCI Thesaurus. Code C6261.

A granulosa-stromal cell tumor that arises from the ovary. It is characterized by the presence of granulosa cells that comprise at least ten percent of the cellular population. The granulosa cells are often found in a background that contains theca and fibrous cells. There are two major subtypes recognized, adult and juvenile granulosa cell tumor. Clinically, patients may present with an abdominal mass. Symptoms depend on the patient's age. The most important indicator of prognosis is tumor stage. Age over forty years at the time of the initial diagnosis, large tumor size, bilaterality, cellular atypia, and increased mitotic activity are factors indicating a potentially aggressive clinical course and relative poor prognosis. 